УДК 323.1 (=161.2) «185/193»

DOI: https://doi.org/10.33782/eminak2019.4(28).358

\title{
СОБОРНІСТЬ ЯК СКЛАДНИК РОЗВИТКУ НАЦІОНАЛЬНОЇ ІДЕНТИЧНОСТІ УКРАЇНЦІВ У ДРУГІЙ ПОЛОВИНІ ХІХ - ПЕРШІЙ ТРЕТИНІ ХХ СТОЛІТТЯ: НОВІТНЯ ІСТОРІОГРАФІЯ
}

\author{
Наталія Семергей \\ Українська медична стоматологічна академія (Полтава, Україна) \\ e-mail: nsemergey@ukr.net \\ ORCID: https://orcid.org/0000-0002-3095-3131
}

\begin{abstract}
у статті розглянуто набуток новітньої історичної науки про ментальний вимір української соборності у другій половині ХІХ - першій третині ХХ століття. З'ясовано, що у чималій кількості історичних синтез про генезу української соборності загалом, дослідження місця та ролі соборності у розвитку етноментальної ідентичності українців представлені досить скромно. Виявлено, що історики розглядають украӥнське національно-культурне відродження як період активного формування ідеї та інституційного оформлення української соборності не лише у територіальному, але й у ментальному вимірах. Зазначено, що з-поміж етапів розвитку концепту соборності на ментальному рівні історики називають політизацію національного руху у другій половині XIX ст., зустріч східних і західних українців на фронтах Великої війни, проголошення Акта Злуки 1919 року, інтеграцію українських земель у політиці українізації 1920-х років.
\end{abstract}

Ключові слова: соборність, новітня українська історіографія, національнокультурне відродження, національна ідентичність, Акт Злуки 1919 року, ментальність

Просторові й історичні умови розвитку України унеможливлюють розгляд української соборності як суто внутрішнього атрибута нації. 3 огляду на географічне розселення українців, етнічна територія проживання яких знаходиться на межі Східної та Західної цивілізацій, проблема української соборності набуває геополітичного та міжнародного звучання. Українцям, окрім тривалого внутрішнього розбрату та штучного розділу в межах інших держав, доводилося постійно спростовувати історіософські концепції про протистояння в українському вимірі східної та західної цивілізацій (Р.Кіплінг), про лінію цивілізаційного поділу, що проходить центром країни (С. Гантінгтон), або ж намагатися редукувати цілком слушні застереження, які висловив І. Лисяк-Рудницький про силу-силенну забобонів, упереджень, образ і претензій, якими упродовж століть обросли відносини Східної та Західної України. Все це значно актуалізує ментальний вимір української соборності, який, як стверджує новітня історіографія, $є$ значно цивілізаційно сильнішим за територіальний.

Статус цементуючого ферменту нації, без сумніву, належить ідеї соборності, ціннісне обгрунтування, суспільна легітимація й інституційне оформлення якої є ключовим індикатором завершеності націєтворчих процесів всередині етносу. Українська соборність має тривалу історію, а постмодерні трансформації, які сьогодні переживає країна, раз у раз стають верифікацією міцності ї̈ політичних, духовнокультурних, соціальних, правових та інших підвалин. Виняткову роль в уречевленні й оприсутненні соборності відіграло українське національно-культурне відродження другої половини XIX - першої третини XX ст. Концептуально-теоретична цінність аналізу генези української соборності у цей період визначається її поетапною крис- 
талізацією, від виголошення гасла до правової та політичної інституціалізації. У наші дні історичне осмислення проблематики соборності України актуалізується зі зрозумілих причин і пояснюється прагненням забезпечити інтелектуальний (науковий) захист територіальної цілісності, суверенітету, неподільності та непорушності кордонів України. Більше того, осмислення ментально-етнічного виміру ґенези української соборності дає змогу науково правильно розглядати питання ціннісної, етнопсихологічної та духовно-культурної єдності української модерної нації.

Тема української соборності $є$ однією з центральних у новітньому українознавчому дискурсі. Складно знайти історика XIX-XX ст., який би не намагався пояснити окремі аспекти історичних умов, сутності та значення реалізації одвічного прагнення українства до територіальної та ментальної єдності. Науково-історичне осмислення ідейно-смислових, інституційних засад і цивілізаційного виміру української соборності як складника національної ідентичності у другій половині XIX - першій третині XX ст. представлено у наукових надбаннях, зокрема, таких учених як В. Верига ${ }^{1}$, В. Верстюк ${ }^{2}$, П. Гай-Нижник ${ }^{3}$, В. Гоцуляк ${ }^{4}$, І. Гошуляк ${ }^{5}$, Я. Грицак ${ }^{6}$,

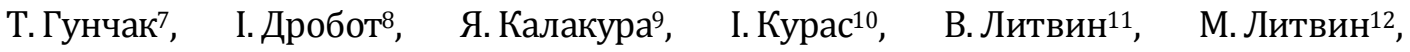
I. Нагаєвський ${ }^{13}$, Ю. Павленко ${ }^{14}$, О. Реєнт ${ }^{15}$, О. Рубльов ${ }^{16}$, В. Сергійчук ${ }^{17}$, В. Смолій ${ }^{18}$,

\footnotetext{
${ }^{1}$ Верига В. Визвольна боротьба в Україні 1914-1923 рр.: у 2 т. 2-е вид. Львів: ВАТ «Рівнен. друк», 2005. Т. 1. 471 с.; Верига В. Визвольна боротьба в Україні 1914-1923 рр.: у 2 т. 2-е вид. Львів: ВАТ «Рівнен. друк», 2005. Т. 2. 494 с.

${ }^{2}$ Верстюк В.Ф. Соборність - наріжний камінь української національної ідеї. Соборність як чинник украӥнсъкого державотворення (до 9о-річчя Акту злуки): Всеукр. наук. конф., Київ, 21 січ. 2009 р. / Ін-т історії України НАН України та ін. Київ, 2009. С. 9-18.

3 Гай-Нижник П.П. УНР та ЗУНР: становлення органів влади і національне державотворення (1917-1920 рр.). Київ: Щек, 2010. 303 с.

4 Гоцуляк В.М. У боротьбі за соборну Україну: державотворча діяльність Симона Петлюри. Хмельницький: ХНУ, 2013. 202 с.

5 Гошуляк І. Тернистий шлях до соборності (від ідеї до Акту Злуки). Київ: ІПіЕНД імені I.Ф. Кураса НАН України, 2009. 467 с.

${ }^{6}$ Грицак Я. Нарис історії України: формування модерної української нації XIX-XX століття: навч. посіб. Київ: Генеза, 1996. 360 с.

7 Гунчак Т. Україна. Перша половина XX століття. Нариси політичної історії. Київ: Либідь, 1993. 288 с. 8 Дробот I. Буковинські українці в боротьбі за соборну державність (1920-1930-ті рр.). Київ, 2002. 67 с.; Дробот I.I. Трансформація української державно-соборницької ідеї (1920-1930-ті роки). Київ: ФАДА, ЛТД, 2002. 343 с.

9 Калакура Я.С. Соборність України як концепт новітньої історіографії. Історична пам'ять. 2015. Вип. 33. С. 116-125; Калакура Я.С. Українська соборність як історіографічна проблема. Соборність як чинник украӥнського державотворення (до 9о-річчя Акту злуки): Всеукр. наук. конф., Київ, 21 січ. 2009 р. / Ін-т історії України НАН України та ін. Київ, 2009. С. 63-78; Калакура Я.С., Рафальський О.О., Юрій М.Ф. Ментальний вимір української цивілізації. Київ: Генеза, 2017. 560 с.; Калакура Я.С., Рафальський О.О., Юрій М.Ф. Українська культура: цивілізаційний вибір. Київ: ІПіЕНД імені І.Ф. Кураса НАН України, 2015. 496 с.

${ }_{10}$ Курас I. Ідея соборності України: історія і сьогодення. Українська соборність: ідея, досвід, проблеми: (До 8о-річчя Акту Злуки 22 січня 1919 р.): [збірник] / Ін-т політ. і етнонац. досліджень НАН України. Київ, 1999. С. 4-11; Курас I., Солдатенко В. Соборництво і регіоналізм в українському державотворенні (1917-1920). Київ: [Б. в.], 2001. 246 с.

11 Литвин В.М. Україна: доба війн і революцій (1914-1920 pp.). Київ, 2003. 488 с.

12 Литвин М.Р., Науменко К.Є. Історія ЗУНР. Львів: Опір, 1995. 362 с.

13 Нагаєвський I. Історія української державності двадцятого століття. Київ: Український письменник, 1993. $412 \mathrm{c.}$

14 Павленко Ю., Храмов Ю. Українська державність у 1917-1919 рр. (історико-генетичний аналіз). Київ: Манускрипт, 1995. 263 с.

15 Реєнт О. Україна соборна: наук. розвідки і рецензії (до 15-річчя незалежності України). Київ, 2006. $131 \mathrm{c}$.
} 
В. Солдатенко 19 й інших. Це далеко неповний «пантеон» вчених, які розглядали історичну ґенезу та зміст досить сакрального для українців концепту «соборності».

Мета статті - проаналізувати новітні історичні дослідження, які присвячені осмисленню місця та ролі ідеї української соборності в розвитку національної ідентичності та ментальних трансформаціях українства у другій половині XIX - першій третині XX ст.

Аналізуючи розвиток ідеї соборності у структурі української етноментальної ідентичності упродовж імперського періоду історики звертають увагу на те, що вперше однойменне гасло було вербалізовано на західноукраїнських землях Головною Руською Радою 1848 р.20. Подальша політизація вимог національного руху, зростання національної свідомості західних і східних українців поступово формували необхідне підгрунтя для реалізації ідеї української соборності у 1919 р. Проголошення Акта Злуки на багато років заклало ментальний і духовно-культурний фундамент для оптимістичного змагання українців XX ст. за утвердження новітньої незалежності.

У сучасній історіографії тематика осмислення української соборності у XIX-XX ст. $\epsilon$ досить обширною. Насамперед, історики зосереджуються на вивченні передумов, чинників, обставин, подій і цивілізаційного виміру ухвалення Акта Злуки, звертають увагу на історичні джерела та специфіку українського поступу соборності. У той же час ментальний вимір соборності, розгляд її як невід'ємного складника української етноментальної ідентичності представлені в українській історіографії значно скромніше.

3-поміж наукових доробків, які присвячені ментальним вимірам соборності України пріоритетне місце належить фундаментальним дослідженням «Ментальний вимір української цивілізації» (Я. Калакура, О.Рафальський, М. Юрій) ${ }^{21}$ і «Тернистий шлях до соборності (від ідеї до Акта Злуки)» (І. Гошуляк)22. Історики розглядають концепт «соборності» не лише у його територіальних, а, насамперед, ментальних і духовно-культурних вимірах, наголошують на його винятковому значенні у контексті відторгнення України від Росії та Польщі.

Цінними є уточнення обсягу та змісту категорії «соборності», яку І. Гошуляк пропонує розглядати у кількох аспектах: 1) об’єднання в одне державне ціле усіх земель, які заселяє конкретна нація на своїй суцільній етнічній території; 2) духовна консолідація населення країни, єдність усіх їі громадян, незалежно від їхньої національності, віросповідання, соціального стану тощо; 3) досягнення суверенної, політично активної, суб'єктної та незалежної державності народу23.

Методологічно цінним для історичного розуміння розвитку феномену соборності в імперську добу та на початку XX ст. $є$ виокремлення Я. Калакурою семи її складників: природно-географічний ландшафт (території формування та самоствердження

\footnotetext{
16 Рубльов О.С. Західноукраїнська інтелігенція у загальнонаціональних політичних та культурних процесах (1914-1939). Київ: Інститут історії України НАН України, 2004. 648 с.

17 Сергійчук В. Українська соборність: Відродження українства в 1917-1920 роках. Київ: Українська Видавнича Спілка, 1999. 412 с.

18 Нариси історії української революції 1917-1921 років / В.А. Смолій та ін. Київ: Наукова думка, 2011-2012. Кн. 1. 390 с.; Кн. 2. 464 c.

19 Солдатенко В.Ф. Українська революція. Історичний нарис. Київ: Либідь, 1999. 976 с.

20 Литвин В.М. Україна: доба війн і революцій (1914-1920 рр.). Київ, 2003. С. 305.

${ }^{21}$ Калакура Я.С., Рафальський О.О., Юрій М.Ф. Вказ. пр.

${ }^{22}$ Гошуляк I. Вказ. пр.

23 Ibid. C. 8.
} 
українського етносу, самодостатність української етнічної території для організації життя соціуму); людський чинник, український етнос (етнічна єдність східних і західних українців, спільність побуту, звичаїв, обрядів, соборна ідентичність за етнічними та громадянськими критеріями); соціокультурний, ідейний, духовно-культурний і ментальний чинники (спільність мови, історичної пам'яті, релігії, менталітету, культурно-історичних травм тощо); фінансово-господарська соборність та економічний суверенітет (збалансований економічний і фінансовий комплекси, цілісність економічної системи, консолідація ресурсів, економічне вирівнювання та поглиблення співпраці); державно-політичний чинник (неперервність хронології українського суспільно-політичного життя, палітра державних утворень Української революції 1917-19121 років, легітимація у суспільстві ідеї соборної державності); захист соборності (військово-оборонний та інформаційний сегмент соборності України, захист їі території та цінностей); геополітичний фактор (міжнародні чинники, які по-різному впливали на процеси утвердження української ідентичності, етнічної консолідації, ворожість сусідів та їхнє прагнення ослабити, розділити та колонізувати Україну, боротьба проти антиукраїнських, сепаратистських, деструктивних та відцентрових сил) ${ }^{24}$.

Аналізуючи особливості становлення ідеї соборності України у другій половині XIX cт. історики наголошують на ї̈ динамічному розвиткові. Так І. Гошуляк виокремлює такі аспекти репрезентації соборності: 1) поява максими П. Чубинського «Станем, браття, в бій кривавий від Сяну до Дону»; соборна діяльність Наддніпрянської України та Галичини в межах Наукового Товариства імені Шевченка; інтелектуальна та просвітницька діяльність М. Драгоманова, його висновки про мовну та етнічну гомогенність українського народу від Кубані до Закарпаття, а також обгрунтування етнічного (етнографічного) принципу визначення національної території українців; літературно-творча спадщина I. Франка, який найголовнішою проблемою уважав «...розчвертування нашої землі і нашого народу і цілковиту відірваність нашу від величезної маси братів наших за кордоном»; діяльність Братства тарасівців, завданням яких була побудова соборної, цілої та неподільної України від Сяну до Кубані, від Карпат до Кавказу; наукові доробки Ю. Бачинського, М. Міхновського; політизація суспільного життя та соборницькі вимоги перших українських політичних партій; поява проекту Конституції соборної України 1905 року; маніфестація та наукове обгрунтування ідеї соборності України М. Грушевським 25.

У сучасній історіографії звертається увага на те, що негативним фактором розвитку соборницького складника етноментальної ідентичності українців напередодні Першої світової війни стала фактична відсутність особистих контактів між населенням Галичини та Наддніпрянщини. Як пояснює О. Рубльов, епізодичність таких взаємин обумовлювалася галицьким консерватизмом, численними та свідомими паспортними перешкодами з боку австрійської та російської адміністрацій. Водночас історик наголошує, що особлива роль у взаємному пізнанні населення Сходу та Заходу відіграла інтелігенція. Галичани знали Наддніпрянську Україну куди менше, як наддніпрянці знали Галичину, бо низка найвидатніших наддніпрянських діячів (меценатів, письменників, політичних емігрантів) приїздили до Галичини та зберігали

\footnotetext{
24 Калакура Я.С. Соборність України як концепт новітньої історіографії... С. 117-119; Калакура Я.С., Рафальський О.О., Юрій М.Ф. Вказ. пр. С. 373-375.

25 Гошуляк I. Вказ. пр. С. 44-61.
} 
зі Львовом тісні відносини 26.

Політичні контексти Першої світової війни виявляли низку проблем для розвитку цінностей соборності в українській ідентичності. Українців, насамперед, розділяло ставлення до воюючих сторін. Населення західних земель орієнтувалося на поразку імперіалістичних сил Росії, вірили, що її розпад відкрив би шанс для утворення самостійної незалежної держави. Водночас лідери українського руху Наддніпрянщини мали русофільські орієнтації, пов'язуючи майбутнє українських земель із пріоритетами автономізму.

У той же час Першу світову війну розглядають й у конструктивній площині щодо розвитку української соборності. Спільною є думка істориків про те, що попри трагічність Першої світової війни ї̈ фронт став зустріччю східних і західних українців, а контакти сприяли формуванню нових елементів ментальної ідентичності. Згадуваний вже О. Рубльов зазначав, що внаслідок мілітаризованого протистояння відносини між східними та західними українцями перейшли у нову якість: «...фронтові колізії й політика поліетнічних Австро-Угорської та Російської імперій викликали потужні переміщення десятків, а то й сотень тисяч людності з західноукраїнських земель на територію підросійської України й на терени власне етнічної Росії, а згодом - у зворотньому напрямі. Інформація про «інших» (підавстрійських, підросійських) українців, усвідомлення власної відмінності/подібності до них із здобутку вузького кола заангажованих (національно свідомих) інтелектуалів ставала надбанням мас, вирішальним чином вплинувши на інтенсифікацію процесу формування загальноукраїнської політичної нації»27.

Якщо О.Рубльов звертав увагу на контакти у середовищі інтелігенції, то Я. Калакура, О. Рафальський і М. Юрій наголошували на вагомому цивілізаційному значенні контактів східних і західних українців у «мундирах». Мова йде про те, що фронт Великої війни обумовив зближення українців Галичини та Наддніпрянщини, а необхідність героїзму та звитяги актуалізувала історичну пам'ять про козацькі часи, демократичне врядування, що значно сприяло усвідомленню соборності та самостійності як української перспективи ${ }^{28}$.

Ключову роль у реалізації ідеї соборності історики відводять проголошенню Акта Злуки 22 січня 1919 р. Слід підкреслити, що його науково-історичне осмислення не позбавлене безпідставної патетики та значних перебільшень. Водночас, історичне та цивілізаційно-ментальне значення документа виняткове. Попри його формальний статус і неможливість практичної реалізації у тогочасних умовах, Акт Злуки відіграв вагому роль у формуванні української модерної нації. Як підкреслювалося у монографії «Ментальний вимір української цивілізації», проголошення соборності було детерміновано історично та свідомісно. Акт Злуки спирався на однаковість східних і західних українців у головному - в їхній споконвічній відданості своїй землі, прагненні до єдності та відновлення незалежності, побудови соборної національної держави. Більше того, історики наголошували, що категорія соборності зароджувалася як стан душі, почуття, мрія і як форма всеукраїнської духовної єдності та мислення, яка мала підгрунтя у формі історичної пам'яті та поступово трансформувалася у реальний рух за об'єднання українських етнічних земель, пов'язаний із націона-

\footnotetext{
${ }^{26}$ Рубльов О.С. Вказ. пр. С. 8.

27 Ibid. C. 8.

${ }^{28}$ Калакура Я.С., Рафальський О.О., Юрій М.Ф. Вказ. пр. С. 334, 338.
} 
льним відродженням і боротьбою за відновлення державності 29.

Критично осмислюючи український історичний процес історики, наскільки дозволяла специфіка історичного пізнання, об'єктивно говорили про негативні наслідки «соборності на папері». Формальність Акта Злуки виявилася не лише у тому, що держави (УНР і ЗУНР) продовжували вести окрему внутрішню та зовнішню політику, порізно вирішувати завдання та визначати майбутнє власної держави, але й у неспроможності швидко відійти від різних ментальних акцентуацій, адже західні українці виросли в умовах впливу європейських традицій, а наддніпрянські - у системі самодержавства та відриву від Європи ${ }^{30}$.

Чинники політичного краху Акта Злуки історики оцінюють по-різному. Так I. Гошуляк 3-поміж причин його декларативного статусу називає такі: агресія більшовицької Росії, Польщі й інших держав, білогвардійців, негативне ставлення до української справи держав Антанти; внутрішній стан українства, гостра міжпартійна та внутрішньопартійна боротьба, громадянська війна на теренах Наддніпрянщини, поділ на політичні табори, наявність серйозних розбіжностей у питаннях стратегії та тактиці державотворення між провідниками УНР і ЗУНР; інертність і слабка амбіційність щодо соборності, адже тогочасні державники розглядали Акт Злуки винятково як вступний договір до об’єднання республік, а повне територіально-політичне об’єднання відкладалося до скликання всеукраїнського парламенту - Українських Установчих зборів, які повинні були ухвалити основні закони соборної України ${ }^{31}$. До вказаних причин невдач національної боротьби історики додають: політичну недосвідченість і відсутність сталого керівництва; цілковитий провал у співпраці між галичанами та наддніпрянцями; підкорення іноземними державами; опозиція до ідеї української соборності та незалежності з боку національних меншин ${ }^{32}$.

Попри політичну «невдачу» Акта Злуки їі значення для збагачення національних засад української ідентичності виняткове. Проголошення об'єднання східних і західних українців не лише базувалося на міцних історичних основах, але й виявило «природний потяг українського етносу до національної єдності, справедливі прагнення широких народних мас як Сходу, так і Заходу України до об’єднання»33. Виняткову цивілізаційну роль змагань українців за соборність, їхній внесок у розвиток національної ідентичності говорив П.-Р. Маґочій: «Можна лише дивуватися, - твердив історик, - чому так багато етнічних українців боролися й поклали своє життя за ідею незалежності. Несподівано після 1917 року стався справжній енергетичний вибух у політичній, соціальній, культурній та військовій сферах. І навіть коли всі ці зусилля не привели до жаданої незалежності, революційний досвід прищепив українцям міцне відчуття національної мети, яку досягнули, до того ж не після кількох поколінь мирної культурної розбудови, а менш, ніж за п'ятдесят років»34.

Високу оцінку Акта Злуки пропонував й О. Рубльов. Історик зазначав, що документ став знаковою подією вітчизняної історії, адже «відносно паралельне й неза-

29 Ibid. C. 368-369.

зо Тимченко Р. Причини та передумови укладання Акту Злуки 22 січня 1919 р. Украйнсъкий історичний збірник. 2008. Вип. 11. С. 210-211.

${ }^{31}$ Гошуляк I. Вказ. пр. С. 423-424.

$3^{2}$ Магочій П.-Р. Україна. Історія її земель та народів / пер. 3 англ.: Е. Гийдель, С. Грачова,

Н. Кушко, О. Сидорчук; ред. укр. вид. Л. Ільченко; відп. ред. В. Падяк. Ужгород: Вид-во

В. Падяка, 2012. С. 506.

33 Гошуляк I. Вказ. пр. С. 450.

34 Магочій П.-Р. Вказ. пр. С. 506-507.

Eminak, 2019, 4 (28) 
лежне існування до нього Східної України та України Західної, що розвивалися історично у сфері різних мовно-культурних та політичних впливів, і відмінності між якими набували значно більших масштабів і символічної ваги, ніж притаманні багатьом країнам звичайні міжрегіональні відмінності, відтоді дедалі більше синхронізується й поступово синтезується у процесі загальнонаціонального розвитку 35.

Натомість скептично оцінював ідейно-політичну декларацію соборності у 1919 р. Я. Грицак. Історик зазначав, що проголошення Акта Злуки було великою історичною подією, проте вона мала чисто декларативне значення 36 . Невдачі ж української революції історик, насамперед, пов'язував із слабкістю національної бази українського руху, відсутністю соціальної структури української нації. Я. Грицак констатував, що українські лідери були змушені апелювати до політично недорозвиненого селянства $^{37}$. До таких оцінок схильні й інші історики, зокрема М. Котляр, С. Кульчицький, В. Солдатенко й інші.

Спільною для істориків є оцінка ментального виміру соборності, який для України полягав у відмежуванні від Росії та Польщі, в усвідомленні соборності як ціннісного, духовно-політичного та закономірного явища у житті українців. Ментальність та ідентичність потребують символізму, який цілком і повністю був забезпечений Актом Злуки. Сам факт державного проголошення соборності українських земель на кілька десятиріч став ідеалом, невтіленою мрією, символізуючи одвічне прагнення українців Сходу та Заходу до ментальної, духовно-культурної та територіальної єдності ${ }^{38}$.

У новітній історіографії звернено увагу й на те, що після поразки національновизвольних змагань 1917-1921 років ідея української соборності та прагнення до їі реалізації не були втрачені. Мова йде про національне відродження 1920-х років, зокрема українізацію. Як зауважував згадуваний вже О. Рубльов, українізація стала потужним імпульсом активізації й усталення наукових і культурно-мистецьких контактів Східної та Західної України. Засобом такої інтеграції, зокрема, була діяльність Історичної секції Всеукраїнської Академії наук на чолі з М. Грушевським і Наукового Товариства імені Шевченка у Львові ${ }^{39}$.

В історичному та цивілізаційному вимірах значення досягнення соборності українських земель історики оцінюють у контексті появи моделі цивілізованого, неекспансіоністського збирання територій в єдиній суверенній державі. На думку А. Філінюка етнонаціональна консолідація українців базувалася на таких принципах як історичне самоусвідомлення спільності, добровільне волевиявлення, ідеали свободи та незалежності, опора на власні політичні та матеріальні ресурси ${ }^{40}$.

Як бачимо, попри активну увагу спільноти істориків до вивчення феномену української соборності загалом, все ж осмислення розвитку її ментально-етнічних вимірів у другій половині XIX - першій третині XXст. представлено скромніше. Це пов'язано з тим, що ментально-етнічна, ціннісна та духовна тематика належить методологічному мейнстриму цивілізаційної історіографічної парадигми, яка лише

35 Рубльов О.С. Вказ. пр. С. 561.

36 Грицак Я. Вказ. пр. С. 145.

37 Ibid. C. 160.

$3^{8}$ Калакура Я.С., Рафальський О.О., Юрій М.Ф. Вказ. пр. С. 372.

39 Рубльов О.С. Вказ. пр. С. 9.

40 Філінюк А. 100 років братерства та соборності України (злуки УНР і ЗУНР). 10о-річчя злуки УНР та ЗУНР: Збірник матеріалів наукового круглого столу. Кам'янець-Подільський: К-ПНУ імені Івана Огієнка, 2019. С. 10. 
починає завойовувати належне їй місце у новітньому українському історіографічному дискурсі. Однією із фундаментальних праць цієї тематики є колективна монографія «Ментальний вимір української цивілізації», в якій запропоновано цілісне та всебічне осмислення місця та ролі соборницького складника у розвитку етноментальної ідентичності української нації. Основна тематика досліджень сучасними істориками української соборності в окреслений період концентрується навколо висвітлення історичних (насамперед, політичних) умов генези ідеї соборності у другій половині XIX ст., аналізу Першої світової війни під кутом зору змін української ментальності, реінтерпретації Акта Злуки та високій оцінці його цивілізаційного значення. Значно скромніше в історіографії представлені особливості трансформації ідеї української соборності у добу «національного відродження» 1920-х років. Конвенціональним історіографічним положенням звучить думка про те, що концепт української соборності відіграв центральну роль у побудові модерної української ідентичності, актуалізувавши рух тих складників українського менталітету, які забезпечили міцний фундамент консолідації українського соціуму та здобуття новітнього незалежності.

\section{REFERENCES}

Drobot, I. (2002). Bukovynski ukraintsi v borotbi za sobornu derzhavnist (1920-1930-ti rr.) [Bukovynian Ukrainians in the Struggle for Cathedral Statehood (1920s-1930s)]. Kyiv [in Ukrainian].

Drobot, I.I. (2002). Transformatsiia ukrainskoi derzhavno-sobornytskoi idei (1920-1930-ti roky) [Transformation of the Ukrainian state-council idea (1920-1930-ies)]. Kyiv [in Ukrainian].

Filiniuk, A. (2019). 100 rokiv braterstva ta sobornosti Ukrainy (zluky UNR i ZUNR) [100 years of brotherhood and unity of Ukraine (unity of UNR and ZUNR)]. In: 100-richchia zluky UNR ta ZUNR (pp. 5-13). Kamianets-Podilskyi [in Ukrainian].

Hai-Nyzhnyk, P.P. (2010). UNR ta ZUNR: stanovlennia orhaniv vlady i natsionalne derzhavotvorennia (1917-1920 rr.) [UNR and ZUNR: the formation of government and national state formation (19171920)]. Kyiv [in Ukrainian].

Hoshuliak, I. (2009). Ternystyi shliakh do sobornosti (vid idei do Aktu Zluky) [The Thorny Path to Catholicity (From Idea to Act of Communion)]. Kyiv [in Ukrainian].

Hotsuliak, V.M. (2013). U borotbi za sobornu Ukrainu: derzhavotvorcha diialnist Symona Petliury [In the Struggle for Cathedral Ukraine: State-Building Activities by Simon Petliura]. Khmelnytskyi [in Ukrainian].

Hrytsak, Ya. (1996). Narysy istorii Ukrainy: formuvannia modernoi ukrainskoi natsii XIX-XX stolittia [An outline of the history of Ukraine: the formation of the modern Ukrainian nation of the nineteenth and twentieth centuries]. Kyiv [in Ukrainian].

Hunchak, T. (1993). Ukraina. Persha polovyna XX stolittia. Narysy politychnoi istorii [Ukraine. The first half of the twentieth century. Essays on political history]. Kyiv [in Ukrainian].

Kalakura, Ya.S. (2009). Ukrainska sobornist iak istoriohrafichna problema [Ukrainian catholicity as a historiographical problem]. In: Sobornist iak chynnyk ukrainskoho derzhavotvorennia (do 90-richchia Aktu zluky) (pp. 63-78). Kyiv [in Ukrainian].

Kalakura, Ya.S. (2015). Sobornist Ukrainy yak kontsept novitnoi istoriohrafii [Unity of Ukraine as a concept of modern historiography]. Istorychna pamiat, 33, 116-125 [in Ukrainian].

Kalakura, Ya.S., Rafalskyi, O.0. \& Yurii, M.F. (2015). Ukrainska kultura: tsyvilizatsiinyi vybir [Ukrainian Culture: A Civilizational Choice]. Kyiv [in Ukrainian].

Kalakura, Ya.S., Rafalskyi, O.0. \& Yurii, M.F. (2017). Mentalnyi vymir ukrainskoi tsyvilizatsii [The mental dimension of Ukrainian civilization.]. Kyiv [in Ukrainian].

Kuras, I. \& Soldatenko, V. (2001). Sobornytstvo i rehionalizm v ukrainskomu derzhavotvorenni (19171920) [Conciliarism and regionalism in Ukrainian statemaking (1917-1920)]. Kyiv [in Ukrainian].

Kuras, I. (1999). Ideia sobornosti Ukrainy: istoriia i sohodennia [The idea of Ukraine's unity: history and the present]. In: Ukrainska sobornist: ideia, dosvid, problemy: (do 80-richchia Aktu Zluky 22 sichnia 1919 r.) (pp. 4-11). Kiev [in Ukrainian].

Lytvyn, M.R. \& Naumenko, K.Ye. (1995). Istoriia ZUNR [History of ZUNR]. Lviv [in Ukrainian].

Lytvyn, V.M. (2003). Ukraina: doba viyn i revoliutsiy (1914-1920 rr.) [Ukraine: days of wars and 
revolutions (1914-1920)]. Kyiv [in Ukrainian].

Mahochii, P.-R. (2012). Ukraina. Istoriia ii zemel ta narodiv [Ukraine. History of its lands and peoples]. Uzhhorod [in Ukrainian].

Nahaievskyi, I. (1993). Istoriia ukrainskoi derzhavnosti dvadtsiatoho stolittia [History of Ukrainian statehood in twentieth century]. Kyiv [in Ukrainian].

Pavlenko, Yu. \& Khramov, Yu. (1995). Ukrainska derzhavnist u 1917-1919 rr. (istoryko-henetychnyi analiz) [Ukrainian statehood in 1917-1919 (historical-genetic analysis)]. Kyiv [in Ukrainian].

Reient, 0. (2006). Ukraina soborna: naukovi rozvidky i retsenzii (do 15-richchia nezalezhnosti Ukrainy) [Ukraine Cathedral: Scientific intelligence and reviews (up to the $15^{\text {th }}$ anniversary of Ukraine's independence)]. Kyiv [in Ukrainian].

Rublov, O.S. (2004). Zakhidnoukrainska intelihentsiia u zahalnonatsionalnykh politychnykh ta kulturnykh protsesakh (1914-1939) [Western Ukrainian intelligentsia in national political and cultural processes (1914-1939)]. Kyiv [in Ukrainian].

Serhiichuk, V. (1999). Ukrainska sobornist: Vidrodzhennia ukrainstva $v$ 1917-1920 rokakh [Ukrainian catholicity: Ukrainian revival in 1917-1920]. Kyiv [in Ukrainian].

Smolii, V.A. (Ed.). (2011-2012). Narysy istorii ukrainskoi revoliutsii 1917-1921 rokiv [Essays on the History of the Ukrainian Revolution of 1917-1921]. (Volumes 1-2). Kyiv [in Ukrainian].

Soldatenko, V.F. (1999). Ukrainska revoliutsiia. Istorychnyi narys [The Ukrainian revolution. Historical sketch]. Kyiv [in Ukrainian].

Tymchenko, R. (2008). Prychyny ta peredumovy ukladannia Aktu Zluky 22 sichnia 1919 r. [Reasons and Prerequisites for Concluding the Act of Union January 22, 1919]. Ukrainskyi istorychnyi zbirnyk, 11, 203-212 [in Ukrainian].

Verstiuk, V.F. (2009). Sobornist - narizhnyi kamin ukrainskoi natsionalnoi idei [Unity is the cornerstone of the Ukrainian national idea]. In: Sobornist iak chynnyk ukrainskoho derzhavotvorennia (do 90richchia Aktu zluky) (pp. 9-18). Kyiv [in Ukrainian].

Veryha, V. (2005). Vyzvolna borotba v Ukraini 1914-1923 rr. [The liberation struggle in Ukraine from 1914 to 1923]. (Volumes 1-2). Lviv [in Ukrainian].

\section{Nataliia Semerhei}

(Poltava Ukrainian Medical \& Stomatological Academy, Poltava, Ukraine)

ORCID: https://orcid.org/0000-0002-3095-3131

\section{Unity as a Component of the Development of National Identity of Ukrainians in the Second Half of the $19^{\text {th }}$ - the First Third of the $20^{\text {th }}$ Century: Modern Historiography}

Nowadays, the historical understanding of the problem of the unity of Ukraine is analyzed for obvious reasons and is explained by the wish to provide intellectual (scientific) protection of the territorial integrity, sovereignty, indivisibility and Ukraine borders inviolability. Moreover, the comprehension of the mental and ethnic dimension of the genesis of Ukrainian unity makes it possible to scientifically correctly consider the issues of value, ethnopsychological, and spiritual and cultural unanimity of Ukrainian modern nation.

All this significantly actualizes the mental dimension of Ukrainian unity, which, according to modern historiography, is much more civilizationally stronger than the territorial one.

Ukrainian unity was forming for a long time, and the postmodern transformations which the country is experiencing today are the verification of the strength of its political, spiritual, cultural, social, legal and other foundations. The Ukrainian national and cultural revival of the second half of the $19^{\text {th }}$ - first third of the $20^{\text {th }}$ century played an exceptional role in unity achieving.

The conceptual and theoretical value of Ukrainian unity genesis analysis in that period was determined by its gradual crystallization, from the proclamation of the slogan to the legal and political institutionalization.

The latest achievements of modern historical science on the mental dimension of Ukrainian unity in the second half of the $19^{\text {th }}$ - the first third of the $20^{\text {th }}$ century are analyzed in the paper. On the basis of problem-conceptual and comparative-historiographical methodology, it 
has been found out that in a considerable number of historical materials historical synthesis about the genesis of Ukrainian unity in general, the study of place and role of unity in the development of the ethnic identity of Ukrainians are of rather insufficient representation.

It has been exposed that historians consider the Ukrainian national and cultural revival as a period of active formation of the idea and institutional shaping of Ukrainian unity not only in the territorial but also in mental dimensions.

It has been found out that historians consider the meaning of «unity» through such components as natural-geographical landscape, human factor and Ukrainian ethnic, social and cultural, ideological, spiritual and cultural and mental factors, financial-economic unity and economic sovereignty, state and political factor, defense of the unity, its military-defense and information segments, geopolitical factor. It is noted that among the stages of the concept of unity at mental level development, historians name the politicization of the national movement in the second half of the 19th century, the meeting of Eastern and Western Ukrainians on the fronts of the Great War, the proclamation of the Act Zluky (Unification Act) of 1919, and the integration of Ukrainian lands in the policy of Ukrainianization in the 1920s. It is concluded that the comprehension of the development of the mental and ethnic dimensions of Ukrainian unity in the second half of the $19^{\text {th }}$ - the first third of the $20^{\text {th }}$ century in historiography has significant prospects. This is due to the fact that the mental and ethnic, value and spiritual issues belong to the methodological mainstream of the civilizational historiographical paradigm, which starts to gain its proper place in the modern Ukrainian historiographical discourse.

Keywords: unity, modern Ukrainian historiography, national and cultural revival, national identity, the Act Zluky 1919, mentality 